\title{
Evaluation of Okra Hybrids in Vertisols of Andhra Pradesh, India
}

\author{
C. Sarada*, A. Rajani, T. Vijayalakshmi, C. Venkata Ramana, \\ K. Sirisha and L. Naran Naidu
}

Horticulture Research Station, Lam Dr YSRHU, India

*Corresponding author

\begin{tabular}{|l|}
\hline Ke y w or d s \\
Okra, Abelmoschus \\
esculentus L, \\
Growth, Yield, \\
YVMV incidence
\end{tabular}

\section{A B S T R A C T}

Okra (Abelmoschus esculentus L.), locally known as Bhendi or ladies finger, is one of the most important vegetable crop grown in AP in all the seasons. Presently okra is grown in an area of twenty three thousand hectares and production is estimated at about 4.39 metric tonnes. The major problem in okra is yellow vein mosaic virus. The main area is occupied by hybrids from private sector. Different cultivars require different climatic condition and the performance of these entries depend on their adoptability to a particular climate and soil conditions. Hence, the present investigation was done with an objective to evaluate the performance of hybrids from public and private sector in Vertisols of AP during kharif season at Horticultural Research Station, Lam. The trial was conducted with eleven entries consisting of seven hybrids with four checks in RBD replicated thrice. Recommended package of practices and need based plant protection measures were taken. The data was recorded on plant height, number of fruits, days to $50 \%$ flowering, fruit length, fruit girth, average fruit weight yield and \%YVMV incidence. Among the entries, significantly maximum plant height was recorded by BSS-428, whereas $\mathrm{OH}-597$ recorded minimum plant height. Among the hybrids under evaluation, significantly more number of fruits was observed in HOK-152 being on par withBSS-828, AROH-631 and Kaveri -919. Among the hybrids, the highest yield was recorded by Kaveri -555 which is significantly superior to all the entries, followed by Kaveri -919 . The maximum yield recorded by Kaveri -555 may be attributed to 100 fruit weight, fruit length and fruit girth and it came to flowering early. Incidence of YVMV ranged from 6.7 (BSS-828) to 55.1 (AROH-631).

\section{Introduction}

Okra is the only important vegetable crop in Malvaceae family. The Egyptians made the first recorded reference to okra in 1216 A.D. It is originated in tropical Africa and was also grown in Mediterranean region and its wild forms are found in India. It is now grown in all parts of the tropics and during the summer in the warmer parts of the temperate region. It is a semi woody, fibrous herbaceous annual with an indeterminate growth habit. Okra is mainly a self-pollinated crop however; insects such as honey bees do cross-pollination occasionally. Okra is adapted to a wide range of soil. A well-drained fertile soil with an adequate content of organic matter and reserves of the major elements are generally suitable for cultivation. However, some cultivars are sensitive to excessive soil 
moisture. Others are slightly tolerant to salt. Optimum $\mathrm{pH}$ ranges from 6.6 to 8.0. Most cultivars are adapted to high temperature throughout the growing period with little seasonal fluctuation.

Okra is an important vegetable crop grown in Andhra Pradesh. Presently okra is grown in an area of twenty three thousand hectares and production is estimated at about 4.39 metric tones. Okra is generally cultivated throughout the year both in kharif and summer seasons. However, the incidence of Yellow vein mosaic was more during summer season than kharif. It is consumed as fresh vegetable and also used in canning. The major problem in okra is yellow vein mosaic virus. Most of the farmers are cultivating the private hybrids without knowing their performance and suitability to the particular agro climatic zone. Hence, the present investigation was carried out with an objective to find out the suitability of various okra hybrids from public and private sector to find out their suitability and also to study their performance with respect to resistance to yellow vein mosaic disease in Vertisols of AP.

\section{Materials and Methods}

The experiment was conducted at Horticultural Research station, Lam, during 2010-11. The experiment was laid down in Randomized Block design with eleven entries from public and private enterprises, with three replications. The eleven entries were Kaveri919, Kaveri- 555 from Kaveri seeds, AKOH2006-04 from Akola, OH-597, HOK-152 from Syngenta, BSS-828 from Bejo sheetal seeds, NOH-537 from Nirmal seeds, AROH-631 from Ankur seeds, Purbani Kranthi from Parbhani, Arka Anamika from IIHR, Pusa Sawani from IARI, New Delhi. The trial was sown in the month of July. Recommended dose of fertilizer (48:24:24) was applied ain the form of urea, single super phosphate and
Murate of potash. Phosporus was applied as basal dose and Nitrogen and Potassium was applied in three splits at basal, 30 and 45 days after sowing. After field preparation seeds were sown in well-prepared soil in lines with a distance of $60 \mathrm{~cm}$ in rows and plant to plant distance of $30 \mathrm{~cm}$ within the row. Recommended package of practices and need based plant protection measures were taken. The data was recorded on five randomly selected plants from each plot on plant height, number of fruits per plant, days to $50 \%$ flowering, fruit length, fruit girth, average fruit weight yield and \%YVMV incidence. The mean data was analyzed statistically as per the procedure laid by Panse and Sukhathme (1984).

\section{Results and Discussion}

Significant differences were observed among the hybrids in yield and yield attributing characters.

\section{Plant height}

Significant differences were observed among the entries with respect to plant height. Plant height ranged from $105.0 \mathrm{~cm}$ to $196.3 \mathrm{~cm}$. Among the entries, significantly maximum plant height was recorded by BSS-428 $(196.3 \mathrm{~cm})$ whereas $\mathrm{OH}-597$ recorded minimum plant height $(105.0 \mathrm{~cm})$. The variation observed in different hybrids in the present study may be due to genetic nature of the hybrids.

The results are in conformity with the findings of Farook Ali khan et al., (2002). The height of the plant can potentially affect yield as those that are taller are usually more number of nodes contributing for higher yield. However, the taller plants may be prone to lodging in wind prone areas. Keeping this in view, pant height, which is one of the important agronomic and most variable trait 
may be kept in mind during selection programmes aimed at improving desirable traits in okra (Akinyele and Oseikita, 2006).

Plant girth: Significant differences were observed among the hybrids with respect to plant girth. Among the hybrids, significantly maximum plant girth was observed in BSS$828(9.8 \mathrm{~cm})$, whereas lowest stem girth was observed in Pusa sawani $(7.5 \mathrm{~cm})$. The variability observed in different hybrids in stem girth may be due to genetic makeup of the hybrids.

Days to flowering: Significant differences were observed among the cultivars with respect to number of days taken to flowering. Among the hybrids, Kaveri -555 required significantly minimum number of days to first flowering indicating its earliness. The maximum number of days to first flowering was recorded in BSS-828 (42 days) followed by AKOH-2006-04, OH-597, and NOH-537 which were statistically on par with each other. The difference in number of days to flowering might be due to the genetic variation among the cultivars because all the cultural practices were kept uniform for all the cultivars.

The early flowering may be attributed to the genetic makeup of the cultivar. The result are also in accordance with Muhammad Amzad 2001, who reported that okra cultivars differed significantly in all the parameter including the days taken to first flowering. It has been demonstrated that on a general basis, early flowering is detrimental for overall productivity in okra as the source to sink ratio will be potentially limited for effective photosynthesis (Abhayogya et al., 1994). However, earliness is preferable character in cropping systems. Depending on the desire of the breeder or farmer, appropriate selection can thus be made for either early or late maturing plants.
Number of fruits per plant: The data with respect to number of fruits per plant showed significant differences among the cultivars under present study. The number of fruits per plant varied from 13.7 in $\mathrm{AKOH}-2006-04$ to 21.3 in HOK-152.Among the hybrids under evaluation, significantly more number of fruits was observed in HOK-152 (21.3) being on par with BSS-828 (19.1), AROH-631 (18.9) and Kaveri -919 (18.6).

The variation observed in the present study with respect to number of pods per plant may be due to genetic character of the hybrid or it may be due to the non-adoptability of the hybrid to the particular climate and soil condition. The results are in conformity with the findings of Farook Ali Khan et al., (2002), Muhammad Amjad et al., (2001) who also observed variability in number of pods per plant in okra.

Fruit weight: The present data revealed significant differences with respect to 100 fruit weight among the cultivars. The fruit weight ranged from $1.7 \mathrm{~kg}$ in $\mathrm{AKOH}-2006-04$ to $2.8 \mathrm{~kg}$ in Kaveri- 555. Among the hybrids under evaluation, Kaveri -555 recorded maximum 100 fruit weight $(2.8 \mathrm{~kg})$ and it is significantly superior to all the other entries.

Similar results of variation in pod weight was recorded by Ashraful and Hossain (2006), Sachan VK (2006), Farook ali Khan etal (2002) Neeraja et al., (2002) and Srabani and Nath (2003).

Fruit Length: Significant differences were observed among the cultivars with respect to fruit length. Fruit length varied from $12.15 \mathrm{~cm}$ in HOK-152 to 17.57 in Kaveri- 555. Among the cultivars, Kaveri -555 recorded maximum fruit length $(17.57 \mathrm{~cm})$ being on par with Kaveri -919. The variability observed in fruit length may be due to varietal character of the particular hybrid under observation (Table 1). 
Table.1 Performance of okra hybrids for growth, yield attributes and yield

\begin{tabular}{|c|c|c|c|c|c|c|c|c|c|}
\hline Entry name & $\begin{array}{c}\text { Plant } \\
\text { Height } \\
\text { (Cm) }\end{array}$ & $\begin{array}{l}\text { Plant } \\
\text { girth } \\
(\mathrm{Cm})\end{array}$ & $\begin{array}{c}\text { Days to } \\
\text { first } \\
\text { flowering }\end{array}$ & $\begin{array}{c}\text { Number } \\
\text { of } \\
\text { fruits- } \\
\text { Plant }\end{array}$ & $\begin{array}{c}100 \\
\text { pod wt } \\
(\mathrm{Kg} / \mathrm{pl})\end{array}$ & $\begin{array}{l}\text { Fruit } \\
\text { length } \\
(\mathrm{Cm})\end{array}$ & $\begin{array}{l}\text { Fruit } \\
\text { girth } \\
(\mathrm{Cm})\end{array}$ & $\begin{array}{l}\text { Yield } \\
\text { (Q/ha }\end{array}$ & $\begin{array}{c}\% \\
\text { Incidence } \\
\text { of } \\
\text { YVMV }\end{array}$ \\
\hline Kaveri -919 & 162.8 & 9.2 & 40.0 & 18.6 & 2.5 & 16.48 & 6.5 & 57.13 & $\begin{array}{c}23.9 \\
(29.2)\end{array}$ \\
\hline $\begin{array}{l}\text { AKOH- } \\
2006-04\end{array}$ & 115.3 & 8.8 & 41.0 & 13.7 & 1.70 & 13.07 & 5.73 & 32.49 & $\begin{array}{c}45.5 \\
(44.4)\end{array}$ \\
\hline OH-597 & 105.0 & 9.0 & 41.0 & 17.1 & 1.80 & 13.77 & 6.42 & 56.22 & $\begin{array}{c}29.8 \\
(32.9)\end{array}$ \\
\hline BSS-828 & 196.3 & 9.8 & 42.3 & 19.1 & 2.07 & 12.75 & 6.52 & 51.42 & 6.7 (14.9) \\
\hline NOH-537 & 143.0 & 9.4 & 41.7 & 16.0 & 1.90 & 13.03 & 6.35 & 47.79 & $\begin{array}{c}43.2 \\
(41.1)\end{array}$ \\
\hline AROH-631 & 146.3 & 9.4 & 38.0 & 18.9 & 1.95 & 13.70 & 6.48 & 51.34 & $\begin{array}{c}55.1 \\
(47.9)\end{array}$ \\
\hline Kaveri -555 & 145.1 & 9.3 & 31.0 & 17.2 & 2.80 & 17.57 & 7.57 & 76.29 & $\begin{array}{c}10.3 \\
(18.7)\end{array}$ \\
\hline HOK-152(c) & 157.0 & 9.9 & 38.7 & 21.3 & 2.00 & 12.15 & 6.28 & 48.03 & $\begin{array}{c}17.6 \\
(24.5)\end{array}$ \\
\hline $\begin{array}{l}\text { Purbani } \\
\text { Kranthi }\end{array}$ & 132.1 & 9.0 & 38.0 & 16.8 & 1.98 & 13.05 & 6.13 & 54.15 & $\begin{array}{c}51.9 \\
(46.1)\end{array}$ \\
\hline $\begin{array}{l}\text { Arka } \\
\text { Anamika } \\
\end{array}$ & 120.3 & 8.6 & 38.7 & 13.5 & 1.82 & 13.40 & 6.84 & 46.55 & $\begin{array}{c}50.6 \\
(45.3)\end{array}$ \\
\hline Pusa Sawani & 128.9 & 7.5 & 38.7 & 18.5 & 1.87 & 12.38 & 6.18 & 36.7 & $\begin{array}{c}17.0 \\
(24.3)\end{array}$ \\
\hline $\mathrm{CD}$ & 22.65 & 1.11 & 2.01 & 2.61 & 0.44 & 2.59 & 0.67 & 14.96 & 5.4 \\
\hline C. V\% & 9.41 & 7.16 & 3.03 & 8.83 & 12.72 & 11.01 & 6.11 & 17.28 & 9.43 \\
\hline
\end{tabular}

The difference in fruit length might be due to the differences in genetic makeup of the cultivars and their response to prevailing environmental conditions. Similar results of variation if fruit length in okra genotypes was reported by Muhammad Amzad (2001), Saifullah and Rabbani (2009) and Anwanobong (2015).

Fruit Girth: Significant differences were observed among the cultivars with respect to fruit girth also. Fruit girth varied from 6.13 in Parbani Kranthi to 7.57 in Kaveri- 555. Among the cultivars, Kaveri -555 recorded significantly maximum fruit length $(7.57 \mathrm{~cm})$.
The variability observed in fruit girth may be due to varietal character of the particular hybrid under observation. Similar results of variation in pod weight were recorded by Ashraful and Hossain (2006) and Sachan (2006).

Yield: Among the hybrids, the highest yield was recorded by Kaveri- 555 (76.29 q/ha) which is significantly superior to all the entries, followed by Kaveri -919 (57.13 q/ha). The maximum yield recorded by Kaveri- 555 may be attributed due to 100 fruit weight $(2.8$ $\mathrm{kg} / \mathrm{pl}$.), fruit length $(17.57 \mathrm{~cm})$ and fruit girth $(7.57 \mathrm{~cm})$ and it came to flowering early 
(31days). Similar results of differences in green fruit yield of okra genotypes were obtained by Farook Ali Khan et al., (2002), Muhammad Amzad (2001) Neeraja et al., (2002) and Srabani and Nath (2003), Eshiet and Brisibe (2015).

Incidence of YVMV - The present study indicated that none of the hybrids were found to be immune to YVMV incidence. Incidence of YVMV ranged from 6.7 (Bss-828) to 55.1 (AROH- 631). The varying level of disease severity could be attributed to the response of entries to YVMV incidence. The climatic conditions especially temperature and humidity may directly influence the vector (white fly) population (Samarjeewa and Rathnayaka, 2004). Among the hybrids, AROH- 631 was highly susceptible to YVMV incidence followed by Parbani Kranthi. Similar type of screening for incidence of yellow vein mosaic in okra has been reported by Phad et al., (2009) and Mahaveer Deshmukh et al., (2011).

\section{References}

Akinyele BO, Oseikita OS (2006) Correlation and path coefficient analyses of seed yield attributes in okra (Abelmoschus esculentus (L.) Moench). African Journal of Biotechnology 5: 1330-1336

Ashraful AKM, Hossain MD (2006) Variability of different yield contributing parameters and yield of some okra (Abelmoschus esculentus L) accessions. J Agric Rural Dev 4: 119-127.

Deshmukh ND, BP Jadhav, IS Halakude and JC Rajput (2011) Identification of new resistant sources for yellow vein mosaic virus disease of Okra (Abelmoschus esculentus L.). Vegetable Science 38(1): 79-81
Eshiet AJ, Brisibe EA (2015) Morphological Characterization and Yield Traits Analysis in Some Selected Varieties of Okra (Abelmoschus esculentus L. Moench). Adv Crop Sci Tech 3(5): 197. -202

Farooq Ali Khan, Jalal ud din, Abdhul Ghaffoor and Kashif Waseem Khan (2002). Evaluation of different cultivars of Okra (Abelmoshos esulantus L.) under the agro -climatic conditions of Dera Ismail Khan. Asian Journal of plant Sciences Vol.1 No.6:663664.

Muhammad Amjad, Muhammad Sultan, Muhammad Akbar Anjum, Chaudhry Muhammad Ayyub and Muhammad mushtaq 2001. Comparative Study on the Performance of Some Exotic Okra Cultivars. International Journal of Agriculture \& Biology Vol 3(4):423-425.

Neeraja, G., Gautham, B. and Reddy, I.P. (2002). Comparative yield trail in okra (Abelmoschus esculentus (L.) Moench) hybrids under southern telanga zone of Andhra Pradesh. Orissa J. Hort., 30(2): 20-22.

Phad GN, AB Suryawanshi, DA. Agale and SR. Chavan (2009). Performance of New Hybrids of Okra [Abelmoschus esculentus (L.) Moench] For Yield, Yellow Vein Mosaic Virus and Fruit Borer. International Journal of Plant Protection, Vol. 2 No. 1: 140-141

Sachan VK (2006) Performance of okra (Abelmoschus esculentus L.) varieties in midhills of Sikkim Orissa. Journal of Horticulture 34: 131-132.

Saifullah M, Rabbani MG (2009) Evaluation and characterization of okra (Abelmoschus esculentus L. Moench.) genotypes. SAARC J Agric 7: 91-98.

Srabani, Debnath and Nath, P.S. (2003). Performance of okra varieties in relation to yield and tolerance to YVMV. Ann. Pl.Protec. Sci., 11(2): 400-401.

\section{How to cite this article:}

Sarada, C., A. Rajani, T. Vijayalakshmi, C. Venkata Ramana, K. Sirisha and Naran Naidu, L. 2018. Evaluation of Okra Hybrids in Vertisols of Andhra Pradesh, India. Int.J.Curr.Microbiol.App.Sci. 7(03): 3050-3054. doi: https://doi.org/10.20546/ijcmas.2018.703.354 